\title{
THE DIRECT INCOME REDISTRIBUTIONAL EFFECTS OF AN IRRIGATION PROJECT
}

\author{
Elizabeth A. Gardiner ${ }^{1}$
}

\section{INTRODUCTION}

In both Canada and the United States the economic decision-making criterion used in the evaluation of public investment in water development projects has typically been the efficiency criterion; that is the benefits of a project, to whomsoever they accrue must exceed the costs to whomsoever they accrue. However, it is now recognized that economic efficiency is not the only, nor even necessarily the most important, objective of many such public investments. ${ }^{2}$ Achieving desirable income redistributive effects is frequently an objective.

The purpose of this paper is first to look at the income redistributional objective and at the problems raised by its incorporation into the economic decision-making criteria for public investments; and second to analyze the potential distribution of benefits from public investment in an irrigation project.

\section{THE INCOME REDISTRIBUTIONAL OBJECTIVE}

Public investments in water development projects typically cause changes (desirable or undesirable) in the distribution of income among members of society. If redistribution could be costlessly accomplished after the fact, then it would be possible to evaluate all such investments from the point of view of the efficiency criterion, making the desired distributional adjustments afterward. However, there is no practicable and costless method of achieving this redistribution. This means that any method of implementing redistributional objectives;

...through pricing and fiscal policies or through incorporating redistributional objectives into public investment criteria may lead to losses in aggregate consumption; it is a matter of judgement whether the conflict between maximizing the size of the pie and achieving the optimal slicing is decreased more by one or the other means of achieving redistributional goals. ${ }^{3}$

However, attempts to incorporate redistributional objectives directly into public investment decision-making criteria necessarily involve problems

$\mathbf{1}_{\text {The author is a doctoral student in Resource Economics at the University }}$ of Michigan.

${ }^{2}$ For ample evidence of this see United States Water Resources Council, Report to the Water Resources Council by the Special Task Force-Standards for Planning Water and Land Resources (Washington, D. C.: July, 1970). 3

Stephen A. Marglin, Public Investment Criteria (Cambridge: The M. I. T. Press, 1967), p. 21. 
both of a technical and of a normative nature. In order to be able to fully evaluate a project from the point of view of redistributional objectives, one needs to be able to answer questions such as the following:

Benefits:

1. Who should benefit?

2. What groups actually do benefit?

3. How much are the total benefits of the project?

4. What is the distribution of benefits among beneficiaries?

5. What is the current distribution of income and wealth among actual intended beneficiaries?

Costs:

6. Who should pay the costs?

7. What groups actually do pay the costs?

8. What are the total costs of the project?

9. How are the total costs distributed among the burdened group?

10. What is the current distribution of income and wealth among the actual and among the intended burdened groups?

Questions one and six are of a normative nature involving value judgements about the desirable distribution of the project's benefits and costs. The other questions involve mainly technical problems in the measurement of benefits and costs and their actual distributional impact.

Methods for determining the specific nature of the value judgement have interested some authors, as have techniques for incorporating this judgement, once specified into the benefit-cost framework.

Consider first, ways of incorporating the value judgement into the benefit-cost framework. Some writers have proposed using constraints or a weighted objective function in order to accomplish this. 4 However, making the value judgement specific, so that the level of the constraint or the relative weights can be determined is no small problem. Some have attempted

.4 For detailed discussion of the se see Stephen A. Marglin, op. cit.; Stephen A. Marglin, "Objectives of Water Resource Development: A General Statement" in Arthur Maass et al., Design of Water Resource Systems (Cambridge: Harvard University Press, 1962), pp. 17-87; Arthur Maass, "Benefit-Cost Analysis: Its Relevance to Public Investment Decisions," in Water Research, Allen V. Kneese and Stephen C. Smith (eds.) (Baltimore: The Johns Hopkins Press for Resources for the Future, Inc., 1966), pp. 311328 or A. Myrick Freeman, III, "Project Design and Evaluation with Multiple Objectives" in Robert H. Haveman \& Julius Margolis (ed.) Public Expenditures and Policy Analysis (Chicago: Markham Publishing Co., 1970) pp. 347363. 
to derive such weights from previous political decisions. 5 Furthermore, it is risky to apply weights from one project to another, or from one period in time to another. Political processes such as "log-rolling" may cause variation from one project to another, and it is also doubtful if a politically derived weight holds constant through time.

An alternative approach to avoid the specific determination of the weights is simply to present the benefit and cost distributions as material to supplement the efficiency benefit-cost ratio and thus give the political decision-maker a more comprehensive base of information to guide his decisions. 6 This approach ignores all of the problems concerning the value judgement, simply leaving it to the political decision-maker, and is limited to technical problems in the measurement of the distributional impact of benefits and costs. 7

Although the normative problems may be avoided by the latter approach, the technical problems cannot be avoided if income redistribution is to be regarded as a serious objective. Overcoming these technical problems is no mean task. To my knowledge there is no case where a complete analysis of the distributional impact of both the benefits and the costs of a public program has been made. ${ }^{8}$ An article by James T. Bonnen provides a good description

${ }^{5}$ See for example Burton A. Weisbrod, "Income Redistributive Effects and Benefit-Cost Analysis," in Problems in Public Expenditure Analysis, Samuel B. Chase, Jr. (ed.) (Washington, D. C.: The Brookings Institution, 1968), pp. 177-222; and also Robert H. Haveman, Water Resource Investment and the Public Interest (Nashville, Tennessee: Vanderbilt University Press, 1964), Chapter 6.

${ }^{6} \mathrm{John}$ V. Krutilla and Otto Eckstein use this approach in looking at the income distributional effects of the potential tax burden imposed by a project. Roland McKean suggests an exhibit showing the effects of the project with respect to multiple objectives one of which could be income redistribution. The 1970 Task Force Report to the Water Resources Council suggests an exhibit or accounting system as well. One of the accounts suggested is the Social Being Account, which includes income redistributional effects. See John V. Krutilla and Otto Eckstein, Multiple Purpose River Development (Baltimore: The Johns Hopkins Press for Resources for the Future, Inc., 1965); Roland N. McKean, Efficiency in Government through Systems Analysis (New York: John Wiley \& Sons Inc., 1958) \& United States Water Resources Council, op. cit., pp. III-E-3 to III-E-10.

${ }^{7}$ A major limitation of this approach is that efficiency is the only criteria used by planners. No specific information such as trade-off ratios between efficiency and income redistribution are available for use at the planning stage.

8 James T. Bonnen, "The Distribution of Benefits from Cotton Price Supports" in Samuel B. Chase, op. cit., pp. 223-254 is a good example of the work that has been done to date. 
of the problems involved in such an analysis. 9

The following section of this paper tackles the technical problem of analyzing the distribution of the benefits of an irrigation project. A complete analysis would of course consider the cost distribution as well. However, all that is known about the project's probable financing is that it would involve a fifty-fifty federal-provincial cost sharing scheme. Nothing is known of how each would finance its share. Even if the type of financing were known, the incidence of the burden would not necessarily $b$ obvious. The literature on tax incidence specifies many situations in which the incidence of the tax is shifted. For purposes of this paper it is assumed that the project will be financed out of general federal and provincial tax revenues and that the marginal effect of the project on any individual taxpayer will be minimal. This being the case the distributional impact of costs can be ignored and the impact of the benefits concentrated upon.

\section{DISTRIBUTION OF DIRECT IRRIGATION BENEFITS FROM THE COULTER- PATTERSON PROJECT}

The Project

The Coulter-Patterson Project, has been under study for some time by both the Water Control and Conservation Branch of the Manitoba Government's Department of Mines and Natural Resources (formerly of its Department of Agriculture and Conservation) ${ }^{10}$ and by the Canada Department of Regional Economic Expansion's (formerly the Department of Agriculture's) Prairie Farm Rehabilitation Association (PFRA), 11 and according to studies conducted to date it meets the standard test of economic efficiency. If constructed, the Project would irrigate between 7,000 and 10,280 acres of land in the Souris River Basin of southwestern Manitoba. PFRA has estimated the direct irrigation

${ }^{9}$ James T. Bonnen,"The Absence of Knowledge of Distributional Impacts: An Obstacle to Effective Public Program Analysis and Decisions" in Robert H. Havemen \& Julius Margolis, op. cit., pp. 246-270.

${ }^{10}$ V. M. Austford, "Interim Report on Measures to Supplement Low Flows on the Souris River in Manitoba, " Province of Manitoba, Department of Agriculture and Conservation, Water Control \& Conservation Branch (Unpub lished Report, May 1964).

${ }^{11} \mathrm{~T}$. Riecken, "Souris River Development-Economic Appraisal of the Proposed Coulter and Gainsborough (Patterson) Dams," Canada Department of Agriculture, Prairie Farm Rehabilitation Administration (Unpublished Report, nd.). 
benefits at 5,941,700 dollars, 12 the costs at 3,780,800 dollars and net benefits at $2,160,900$ dollars.

Method of Analysis

The method of analyzing the distribution of the direct irrigation benefits of the Coulter-Patterson Project is briefly outlined as follows:

(1) A beneficiary group composed of actual farmers in the vicinity of the Project is constructed.

(2) The distribution of income and wealth among the members of this beneficiary group is then determined.

(3) The distribution of the Project's direct irrigation benefits among the beneficiaries is analyzed.

(4) The distribution of benefits is compared with the original income and wealth distribution.

\section{The Beneficiary Group}

Although the PFRA study tells us how many acres the Project has the capacity to irrigate, and estimates the total of the direct irrigation benefits, it gives no information with regard to the potential distribution of the se benefits.

In this study, it has been decided to construct a beneficiary group which, although it may not be an exact estimate of the actual group, can at least be expected to approximate the actual group with respect to its wealth distributional structure.

Using soil reports and maps ${ }^{13} 720$ acres of irrigable valley land and 6,920 acres of irrigable topland are located in the vicinity of the Project.

${ }^{12}$ Although the PFRA report measures only direct irrigation benefits, other direct benefits such as the provision of water for domestic and municipal demands were also expected to accrue. The value of direct benefits is therefore somewhat underestimated when only direct irrigation benefits are included.

${ }^{13}$ W. Michalyna and L. A. Hopkins, "Preliminary Report on the Irrigation Suitability of the Soils of the Souris, Antler and Gainsborough Channels, including map" (Unpublished Report for the Canada Department of Agriculture and Manitoba Department of Agriculture, Nov., 1967), and W. Michalyna, "Preliminary Report on the Irrigation Suitability of the Soils in the South Half of the Virden Map Sheet, with a map showing land classification" (Unpubl ished Report for the Canada Department of Agriculture, October, 1967). 
This combination is a feasible one for the Project to irrigate with its capacity. Through the use of data on land ownership provided by the assessment Branch of the Manitoba Government, it is possible to determine who owns this land, the size of the owner's farm, and the 1966 assessed value of that farm. 14 Forty farms of varying sizes, irrigable acreages and assessed values are accounted for in this manner, and they make up the beneficiary group.

Assessed farm value is used as a proxy for the wealth positions of the members of the group. 15 The present distribution of wealth, measured by assessed farm value, is presented in Table 1.

The Lorenz curve for this distribution is shown in Figure 2 and the Gini Coefficient is calculated to be .28.16

${ }^{14}$ Data used in the PFRA report were from 1961. Only 1966 assessed farm values were available for farmers in the area around the CoulterPatterson Project. However relative assessed values are not likely to change from one assessment to the next, so 1966 relative values will also reflect 1961 relative values.

${ }^{15}$ The other alternative that could have been utilized was farm size. To get an idea of the relationship between farm size and net worth (wealth) and of that between net worth and income, 1966 data for 43 owner operated farms in the Southwestern Manitoba Farm Business Association were obtained from the Economics and Publications Branch of the Manitoba Department of Agriculture. An $\mathrm{r}^{2}$ coefficient of . 3 was obtained for the correlation between farm size and net worth for these farms, and a coefficient of .4 for the correlation between net worth and net farm income. Averaging net worth, net farm income and farm size for each of eight farm size categories in the sample, a coefficient of .7 was obtained for the correlation between average farm size and average net worth. Although there are numerous other factors besides farm size which affect net worth, increased farm size on the average means increased net worth. Average net worth and average net farm income were found to be highly correlated with a coefficient of . 8 . In the original study both farm size and assessed farm value were used as proxies for net worth with similar results. There was found to be a correlation of . 9 between the two. See Elizabeth Anne Gardiner, "Extensions to Public Investment Criteria: Application to a Project in the Souris River Basin" (Unpublished: A Master's Thesis presented to the Faculty of Graduate Studies, University of Manitoba, August, 1970). Here assessed farm value is used because it is felt that it is a slightly better or at least no worse proxy for wealth than farm size.

${ }^{16}$ The Gini Coefficient is the ratio of the area between the curve and the diagonal to the area under the diagonal. For a discussion of the derivation of Lorenz Curves and Gini Coefficients see James Morgan, "The Anatomy of an Income Distribution, " Review of Economics and Statistics, XLIV (August, 1962), pp. $270-283$. 
TABLE I

FARMS ARRAYED IN ORDER OF ASSESSED FARM VALUE*

\begin{tabular}{lrlllll}
\hline \hline $\begin{array}{l}\text { Assessed } \\
\text { Value }\end{array}$ & $\begin{array}{l}\text { Average } \\
\text { Assessed } \\
\text { Category }\end{array}$ & $\begin{array}{l}\text { Value of } \\
\text { Category }\end{array}$ & $\begin{array}{l}\text { No. of } \\
\text { Farms }\end{array}$ & $\begin{array}{l}\text { Total } \\
\text { Assessed } \\
\text { Value }\end{array}$ & $\begin{array}{l}\text { Percentage of } \\
\text { Aggregate } \\
\text { Assessed } \\
\text { Value }\end{array}$ & $\begin{array}{l}\text { Percent } \\
\text { of Farms }\end{array}$ \\
\hline \multicolumn{1}{r}{} & & & & & & \\
2,000 & $\$ 1,000$ & 1 & $\$ 1,000$ & .3 & 2.5 \\
$2001-$ & 4,000 & 3,000 & 5 & 15,000 & 4.6 & 12.5 \\
$4001-$ & 6,000 & 5,000 & 8 & 40,000 & 12.3 & 20. \\
$6001-$ & 8,000 & 7,000 & 9 & 63,000 & 19.3 & 22.5 \\
$8001-$ & 10,000 & 9,000 & 4 & 36,000 & 11.0 & 10.0 \\
$10,001-$ & 12,000 & 11,000 & 4 & 44,000 & 13.5 & 10.0 \\
$12,001-$ & 14,000 & 13,000 & 4 & 52,000 & 16.0 & 10.0 \\
$>$ & 14,000 & 15,000 & 5 & 75,000 & 23.0 & 12.5 \\
\hline
\end{tabular}

* Source: Manitoba Department of Municipal Affairs, Assessment Branch, Municipal Assessment Data, 1966, Unpublished.

Distribution of Direct Irrigation Benefits

Knowing the present distribution of wealth among the beneficiary group we now proceed to analyze the distribution of the direct irrigation benefits of the Project among that group.

In order that any of the direct irrigation benefits from the Project accrue to a given farmer, this farmer must undertake private investment in irrigation farming. Assuming that he will, in fact, be willing to undertake private investment, the profitability of this private investment is a measure of the amount of the Project's direct irrigation benefits which will accrue to him. ${ }^{17}$ The distribution of the direct irrigation benefits of the project will be determined by the distribution of profitability in irrigation investment among the farmers concerned. ${ }^{18}$ The sum of the net benefits accruing to each farmer on his

${ }^{17}$ Unwillingness of private investors to undertake such private investment has in cases such as that of the South Saskatchewan River Project resulted in an over estimation of direct irrigation benefits. This benefit over estimation is a problem which should be investigated, but to do so is beyond the scope of this paper.

${ }^{18}$ Benefits could also be gained by the farmers who presently own the land, should they decide to sell rather than irrigate, through the higher sale price of land. However the benefits obtained in this manner would equal the present value of the benefits that would have been gained by investment in irrigation farming. 
investment will give the total direct irrigation benefits of the project. ${ }^{19}$

Consider first of all the purchase price of the good or the initial capital investment in irrigation farming. This includes a part which is fixed over certain ranges of irrigable acreage and a part which is more or less continuously variable with irrigable acreage.

The former part includes the cost of irrigation equipment. In this case, given the topography and soils of the region, sprinkler equipment would be most efficient. It also includes any other investments of a lumpy nature in buildings, machinery or equipment necessitated by the move into irrigation farming.

The type of sprinkler equipment which I shall consider for the purposes of this analysis will be a self-propelled sprinkler system. ${ }^{20}$ Such a system consists of a lateral pipe, affixed with rotating sprinklers, which rotates around a moveable pivot point. Economies of scale are inherent in this system first because the price is proportional to the length of the lateral pipe, or to the square root of the area irrigated. Although this economy is limited by the maximum efficient length of the lateral pipe, other economies are possible because the system can be towed from field to field. This economy is limited by the time requirements for each crop but McMartin and Bergan indicate that irrigating three fields per system is not unreasonable. 21

The latter part of the initial capital investment which is variable with irrigable acreage includes such investments as the purchase of feeder cattle or other livestock. There may or may not be economies of scale here. For present purposes, over the range of acreages considered, it was assumed that such economies were either non-existent or negligible.

Table 2 gives estimates of the fixed, variable and total investment costs in irrigation farming when the sprinkler systems are used in from one to three fields.

19 This is assuming that the private discount rate and social discount rate don't diverge and that there are no constraints on private investment.

${ }^{20}$ This type of equipment is best suited to irrigating field crops in relatively large fields. Providing the farms in the area around the CoulterPatterson Project are not greatly altered in field size and cropping pattern (the PFRA report suggests they wo uld not be) this type of irrigation equipment is fairly well suited to their uses.

21 For a description and evaluation of the self-propelled sprinkler system see Wallace McMartin and Ronald O. Bergan, Irrigation Practices and Costs in North Dakota, Department of Agricultural Economics, Agricultural Experiment Station, North Dakota State University, Bulletin No. 474 (Fargo, North Dakota: (no publ.), 1968). 
TABLE 2

INITIAL CAPITAL INVESTMENT*

\begin{tabular}{lccc}
\hline \hline $\begin{array}{l}\text { System Capacity } \\
\text { one field }\end{array}$ & 50 acres & 100 acres & 150 acres \\
per system & $\$ 9,000$ & $\$ 13,500$ & $\$ 16,500$ \\
\hline Fixed Investment & 1,800 & 3,600 & 5,400 \\
Variable Investment & 10,800 & 17,100 & 21,900 \\
Total Investment & & & \\
\hline System Capacity & & & \\
two fields & $2 \times 50=100$ acres & $2 \times 100=200$ acres & $2 \times 150=300$ acres \\
per system & $\$ 9,000$ & $\$ 13,500$ & $\$ 16,500$ \\
Fixed Investment & 3,600 & 7,200 & 10,800 \\
Variable Investment & 12,600 & 20,700 & 27,300 \\
Total Investment & & & \\
System Capacity & & & \\
three fields & $3 \times 50=150$ acres & $3 \times 100=300$ acres & $3 \times 150=450$ acres \\
per system & $\$ 9,000$ & $\$ 13,500$ & $\$ 16,500$ \\
Fixed Investment & 5,400 & 10,000 & 16,300 \\
Variable Investment & 14,400 & 24,300 & 32,800 \\
Total Investment & & &
\end{tabular}

*Sources: 1. International Pembina River Engineering Board, "Joint Investigation for Development of the Water Resources of the Pembina River Basin. Manitoba and North Dakota, Vol. III, Appendix F Irrigation," (Report to the International Commission, December, 1964), pp. 388-393.

2. T. Riecken, "Souris River Development," p. c-11.

3. McMartin and Bergan, op. cit. , pp. 23-26.

Now the flow of increased net farm income from the investment must be considered. Increased net farm income is the difference between increased receipts and increased expenses accruing as a result of the investment. The increased receipts will be assumed to be continuously variable with irrigated acreage. 22 Fixed expenses include such items as depreciation on fixed capital and such items as purchases of feed, seed and fuel. The water itself is free. Table 3 presents increased receipts, increased fixed expenses, increased

\section{${ }^{22}$ The assumed cropping pattern of the irrigated acreage is taken to be} the same as specified in the Riecken Report: potatoes $20 \%$, cereals $40 \%$ and forage crops $40 \%$. Prices are also taken to be the same as in the report: wheat $(\$ 1.73 / \mathrm{bu}$.), oats $(\$ 0.60 /$ bu. $)$, alfalfa hay $(\$ 22.00 /$ ton $)$, potatoes $(\$ 30.00 /$ ton $)$, finished steers $(\$ 24.00 / \mathrm{cwt})$, purchased feeders $(\$ 22.00 / \mathrm{cwt})$, hired labour with board $(\$ 240.00 /$ month), and interest on farm investment $(6 \%)$. 
variable expenses and increased net farm income for various irrigated acreages. The increase in net farm income given in Table 3 can be expected to accrue throughout the life of the investment. 23 McMartin and Bergan consider the life of the self-propelled sprinkler system to be about 15 years. 24 Other equipment may have a somewhat longer or shorter useful lile. However here it will be considered that on the average, the total investment good will have a useful life of 15 years.

TABLE 3

INCREASED ANNUAL NET FARM INCOME *

\begin{tabular}{lrrr}
\hline \hline Acres Irrigated & \multicolumn{1}{c}{} & \multicolumn{1}{c}{} \\
one field per system & 50 & 100 & 150 \\
\hline Increased Receipts & $\$ 5,800$ & $\$ 1,500$ & $\$ 17,300$ \\
Inc. Fixed Expenses & 1,400 & 2,000 & 2,500 \\
Inc. Variable Expenses & 3,200 & 6,500 & 9,700 \\
Inc. Total Expenses & 4,600 & 8,500 & 12,200 \\
Inc. Net Farm Income & 1,200 & 3,000 & 5,100 \\
\hline Two fields per system & 100 & 200 & 300 \\
\hline Increased Receipts & $\$ 11,500$ & $\$ 23,000$ & $\$ 34,600$ \\
Inc. Fixed Expenses & 1,400 & 2,000 & 2,500 \\
Inc. Variable Expenses & 6,500 & 13,000 & 19,400 \\
Inc. Total Expenses & 7,900 & 15,000 & 21,900 \\
Inc. Net Farm Income & 3,600 & 8,000 & 12,700 \\
\hline Three fields per system & 150 & 300 & 450 \\
\hline Increased Receipts & $\$ 17,300$ & $\$ 34,600$ & $\$ 51,900$ \\
Inc. Fixed Expenses & 1,400 & 2,000 & 2,500 \\
Inc. Variable Expenses & 9,700 & 19,400 & 29,000 \\
Inc. Total Expenses & 11,100 & 21,400 & 31,500 \\
Inc. Net Farm Income & 6,200 & 13,200 & 20,400 \\
\hline
\end{tabular}

* Sources: 1. International Pembina River Engineering Board, "Joint Investigation for Development of the Water Resources of the Pembina River Basin. Manitoba and North Dakota, Vol. III, Appendix F-Irrigation, " (Report to the International Commission, December, 1964), pp. 388-393.

2. T. Riecken, "Souris River Development," p.c-11.

3. McMartin and Bergan, op. eit. , pp. 23-26.

${ }^{23}$ There is, of course, a good deal of risk involved in whether or not the increase in net farm income will actually accrue in any given year, at least in the amount specified. Although the provision of irrigation water reduces the risk element with regard to moisture for the crops, there is still also the question of the length of the growing season and there may also be unstable market conditions.

24 McMartin and Bergan, op. cit., p. 25. 
The Project itself is estimated by PFRA to have a fifty year life. Thus, a second round of private investments can be made at the end of the fifteenth year and these will yield a second set of increases in net farm income accuring throughout the lives of these second investments. Similarly, a third set of investments can be made at the end of the thirtieth and a fourth set at the end of the forty-fifth years. 25 Assuming each of the subsequent sets of investments to be identical to the first set, and to yield identical income streams, the net increases in farm income presented in Table 3 can be said to accure throughout the fifty year life of the Project.

These increases in net farm income must be converted to present value using a discount rate which measures the private opportunity cost rate of return on farm investment; the PFRA report considers this rate to be six percent. These present value figures measure the profitability of private investment in irrigation farming.

TABLE 4

\section{PRESENT VALUES OF FUTURE INCOME STREAMS}

$$
\text { (i }=6 \% \quad \mathrm{~N}=50 \text { years) }
$$

\begin{tabular}{|c|c|c|c|c|c|}
\hline$\overline{\text { Acres }}$ & & Acres & & Acres & \\
\hline $\begin{array}{l}\text { Irrigated } \\
\text { one field } \\
\text { per system }\end{array}$ & $\begin{array}{l}\text { Present } \\
\text { Value }\end{array}$ & $\begin{array}{l}\text { Irrigated } \\
\text { two fields } \\
\text { per system }\end{array}$ & $\begin{array}{l}\text { Present } \\
\text { Value }\end{array}$ & $\begin{array}{l}\text { Irrigated } \\
\text { three fields } \\
\text { pre system }\end{array}$ & $\begin{array}{l}\text { Present } \\
\text { Value }\end{array}$ \\
\hline 50 & $\$ 18,900$ & 100 ac. & $\$ 56,700$ & $150 \mathrm{ac}$. & $\$ 97,700$ \\
\hline 100 & 47,300 & 200 & 126,100 & 300 & 208,000 \\
\hline 150 & 80,400 & 300 & 200,200 & 450 & 321,500 \\
\hline
\end{tabular}

Given the relationship between private investment profitability and irrigable acreage we can now return to the beneficiary group and determine the distribution of direct irrigation benefits within this group.

Table 5 and Figure 1 summarize the necessary information. In Table 5, we have point estimates of direct irrigation benefits for the midpoints of the various irrigable acreage categories. These estimates show both that benefits per farm and benefits per acre increase with increasing irrigable acreage. In

${ }^{25}$ For the fourth period, the fifteen year life investment goods are needed for only five years. However, assuming all investment goods to be marketable at the end of the five year period, annual expenses including depreciation will be the same as for the first five years of any of the previous investments. Given the observable long-term inflationary price trends, the estimated constant annual increases in net farm income would be equivalent to constant dollar net returns. This assumes however that no relative cost or price changes occur between factor inputs and product outputs. 
Figure I taking the distribution of irrigable acreage among farms in different assessed value categories is given and summing across the category we get the total direct irrigation benefits for this category. Percentage benefits, for each assessed value category can then easily be calculated. The total Project benefits are found by summing the total benefits in each category. These are all shown in Table 6.

TABLE 5

VALUE OF DIRECT IRRIGATION BENEFITS PER FARM \& PER IRRIGATED ACRE

\begin{tabular}{llll}
\hline $\begin{array}{l}\text { Category of } \\
\text { Irrigable } \\
\text { Acreage }\end{array}$ & $\begin{array}{l}\text { Midpoint of } \\
\text { Category }\end{array}$ & $\begin{array}{l}\text { Direct Irriga- } \\
\text { tion Benefits } \\
\text { per farm }\end{array}$ & $\begin{array}{l}\text { Direct Irriga- } \\
\text { tion Benefits } \\
\text { per acre }\end{array}$ \\
\hline & & & \\
$<80$ acres & 40 acres & $\$ 11,300$ & $\$ 280$ \\
$81-160$ & 120 & 79,400 & 660 \\
$161-240$ & 200 & 134,500 & 670 \\
$241-320$ & 280 & 194,400 & 700 \\
$321-400$ & 360 & 251,100 & 700 \\
$>400$ & 440 & 315,900 & 720 \\
\hline
\end{tabular}

TABLE 6

BENEFITS ARRAYED IN ORDER OF ASSESSED FARM VALUE

\begin{tabular}{|c|c|c|c|c|c|}
\hline $\begin{array}{l}\text { Assessed } \\
\text { Value } \\
\text { Category }\end{array}$ & $\begin{array}{l}\text { Average } \\
\text { Benefits } \\
\text { per Farm }\end{array}$ & $\begin{array}{l}\text { No. of } \\
\text { Farms }\end{array}$ & $\begin{array}{l}\text { Total } \\
\text { Benefits }\end{array}$ & $\begin{array}{l}\text { Percent } \\
\text { Benefits }\end{array}$ & $\begin{array}{l}\text { Percent } \\
\text { Farms }\end{array}$ \\
\hline$<\$ 2,000$ & $\$ 11,000$ & 1 & 11,000 & .2 & 2.5 \\
\hline $2,001-4,000$ & 52,200 & 5 & 261,000 & 5.4 & 12.5 \\
\hline $4,001-6,000$ & 59,100 & 8 & 473,000 & 9.8 & 20.0 \\
\hline $6,001-8,000$ & 134,000 & 9 & $1,206,000$ & 25.0 & 22.5 \\
\hline $8,001-10,000$ & 88,300 & 4 & 353,000 & 7.3 & 10.0 \\
\hline $10,001-12,000$ & 104,500 & 4 & 418,000 & 8.7 & 10.0 \\
\hline $12,001-14,000$ & 179,000 & 4 & 716,000 & 14.8 & 10.0 \\
\hline \multirow[t]{2}{*}{$>14,000$} & 277,000 & 5 & $1,385,000$ & 28.7 & 12.5 \\
\hline & & & $4,823,000$ & & \\
\hline
\end{tabular}

The Lorenz Curve for the distribution of direct irrigatıon benefits is shown in Figure 2. The Gini Coefficient for the distribution was calculated to be .30 . 
Figure 1

DISTRIBUTION OF IRRIGABLE ACREAGE ACCORDING TO ASSESSED

FARM VALUE

$\$ 14,000$

12,000

10,000

8,000

6,000

4,000

2,000

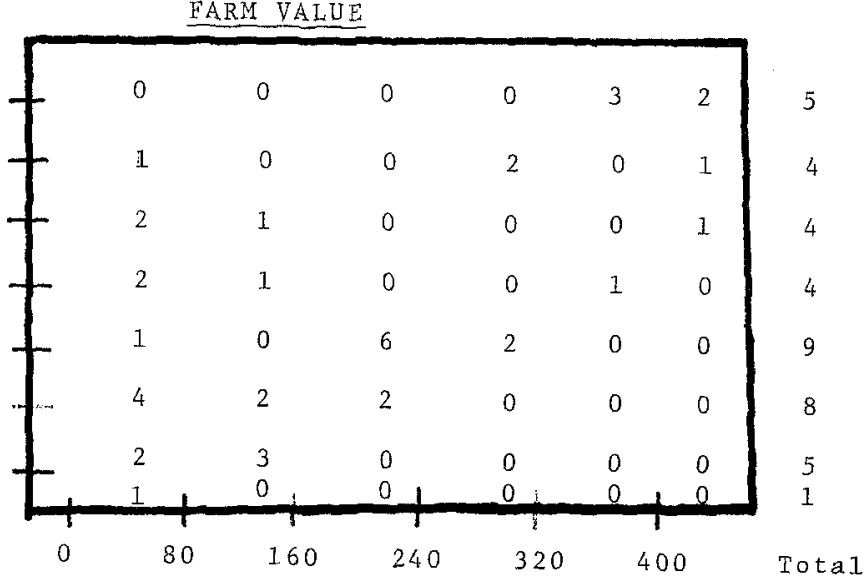

Irrigable Acreage Category

\section{Figure 2}

\section{LORENZ CURVES FOR ASSESSED VALUE AND BENEFIT DISTRIBUTION}

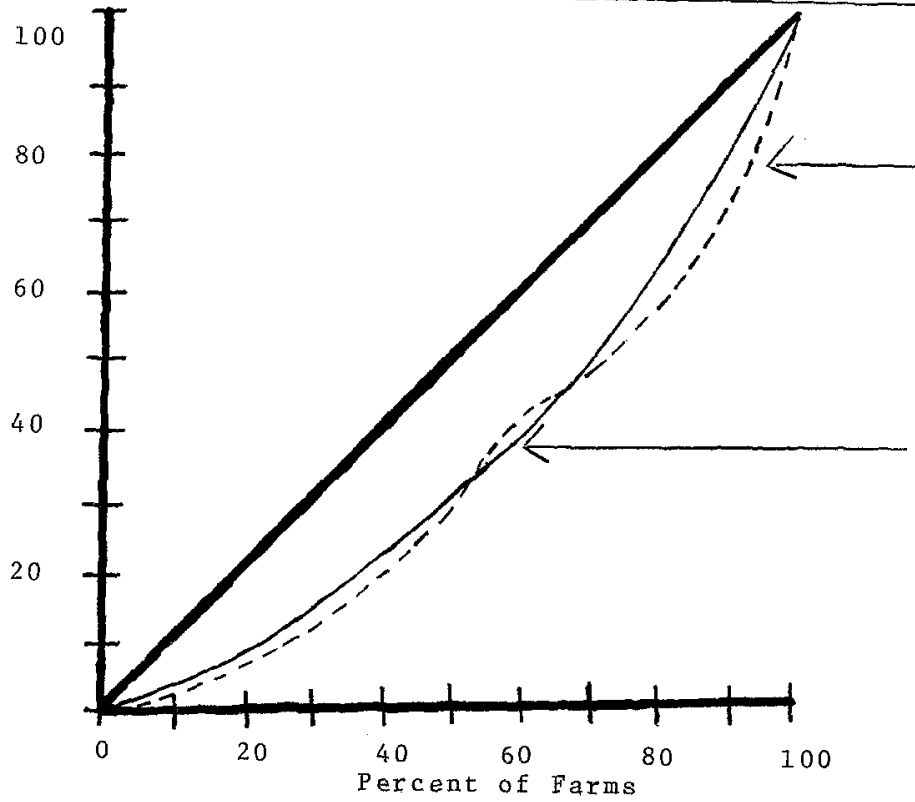

Percent of Direct Irrigation Benefits (Gini Ratio=.30)

Percent of Total Assessed Value (Gini Ratio=.28) 


\section{CONCLUSIONS}

The total direct irrigation benefits accruing to the beneficiary group here total 4, 823, 000 dollars. 26 Comparing the Lorenz Curve for the distribution of these irrigation benefits with that for the present distribution of wealth as measured by assessed farm value one sees that the distribution of the benefits is more unequal than the present distribution of wealth. The Gini Coefficient for the benefit distribution is . 30 as compared to . 28 for the present distribution of wealth. Farmers in the lowest wealth positions (below 6001 dollars assessed farm value) comprise 35.0 percent of the beneficiary group but obtain only 15.4 percent of the benefits. All of this low wealth group have farms less than 321 acres in size. The average net farm income for farms in the Southwestern Manitoba Farm Business Association group "less than 320 acres in size" in 1966 was 900 dollars and the average net worth was 45,700 dollars. Farmers in the highest wealth positions (above 10,000 dollars assessed farm value) comprise 32.5 percent of the beneficiary group and receive 52.2 percent of the benefits. This corresponds to the size group "greater than 480 acres." The average net farm income for the Southwestern Manitoba Farm Business Association farms in this size category was 7,100 dollars and the average net worth was 91,200 dollars. The intermediate category (between 6,001 and 10,000 dollars assessed farm value inclusive) comprises 32.5 percent of the farms and receives 32.3 percent of the benefits. This corresponds to the size group "321 to 480 acres" and this group in the Southwestern Manitoba Farm Business Association had an average net farm income of 4,700 dollars and an average net wealth of 67,500 dollars.

Summarizing we may say that although the Coulter-Patterson Project may meet the standard criterıon of economic efficiency and may distribute direct irrigation benefits to a beneficiary group of farmers in the vicinity of the Project, the distribution of those benefits depends upon the distribution of irrigable acreage, and given economies of scale in irrigation farming and free water ${ }^{27}$ the general pattern of benefit distribution is in favour of those farmers

\footnotetext{
26 PFRA's estimate of $5,941,700$ dollars differs from the estimate here because:

(a) A different combination of irrigable topland and valleyland allows a greater total irrigable acreage than in the PFRA study.

(b) The benefit estimate for a typical 220 acre farm is less in the PFRA study than here.

(c) PFRA's estimate implies a homogeneous group of farms each with 220 acres irrigable. This study contains farms with various amounts of irrigable acreage.

${ }^{27}$ Charging a fixed rate per acre foot of water (i.e., the average cost of provision) would also produce such inequality as benefits per acre are not equally distributed among farms, but are higher for farms with greater irrigable acreages.
} 
with a larger amount of irrigable acreage. As the distribution of income and wealth is directly related to the amount of irrigable acreage this means that those farmers already in the most favourable wealth positions receive the largest portion of the benefits. The average net farm income of farms in this group is well above the average net farm income in Manitoba in 1966, 4, 300 dollars. 28

The project, then, although it may distribute income to some farmers in the Souris Basin does not constitute a very efficient redistributive instrument. As the poorest farmers receive only a small portion of the benefits other income redistributive programs should be investigated.

However, an income redistributional analysis such as this provides an additional criterion for the decision-maker choosing among alternative projects.

27 Dominion Bureau of Statistics, Canada Year Book, 1968 (Ottawa: Queen's Printer, 1968) p. 497, table 9 and p. 526, table 46. 